\title{
THE IMPACT OF BALANCED ENERGY AND PROTEIN SUPPLEMENTATION TO MILK PRODUCTION AND QUALITY IN EARLY LACTATING DAIRY COWS
}

\author{
B. P. Widyobroto ${ }^{1}$, Rochijan ${ }^{1}$, Ismaya ${ }^{2}$, Adiarto $^{1}$ and Y.Y. Suranindyah ${ }^{1}$ \\ ${ }^{1}$ Department of Animal Production, Faculty of Animal Science, Gadjah Mada University, \\ Jl. Fauna No. 3, Bulaksumur, Yogyakarta 55281 - Indonesia \\ ${ }^{2}$ Department of Animal Breeding and Reproduction, Faculty of Animal Science, \\ Gadjah Mada University, Jl. Fauna No. 3, Bulaksumur, Yogyakarta 55281 - Indonesia \\ CorrespondingE-mail: rochijan@mail.ugm.ac.id
}

Received January 01, 2016; Accepted April 27, 2016

\begin{abstract}
ABSTRAK
Penelitian ini dilakukan untuk mengetahui dampak suplementasi energi dan protein seimbang dengan high rumen undegraded protein (HRUP) terhadap produksi dan kualitas susu pada sapi perah awal laktasi. Dua belas ekor sapi Friesian Holstein awal laktasi dibagi menjadi dua kelompok (kontrol dan HRUP). Kelompok kontrol dan HRUP memperoleh pakan basal dengan rasio hijauan dan konsentrat 60:40 (bahan kering), dengan konsentrasi rumen undegraded protein (RUP) masing-masing sebesar 27,47\% (kontrol) dan 32,78\% (HRUP). Pakan diberikan dua kali, pagi dan sore hari. Air minum diberikan secara ad libitum. Variabel yang diamati adalah konsumsi nutrien, produksi dan kualitas susu. Data yang diperoleh dianalisis dengan analisis t-test. Hasilnya menunjukkan bahwa konsumsi nutrien, produksi susu dan $4 \%$ FCM, produksi dan konsentrasi lemak dan laktosa susu, konsentrasi solid non-fat dan total solid susu antara kontrol dan HRUP tidak berbeda nyata $(\mathrm{P}>0,05)$. Namun, produksi dan konsentrasi protein susu antara kontrol dan HRUP menunjukkan nilai yang berbeda nyata $(\mathrm{P}<0,05)$. Disimpulkan bahwa suplementasi energi dan protein seimbang dengan HRUP pada sapi perah awal laktasi tidak memberikan dampak terhadap produksi susu dan 4\% FCM, produksi dan konsentrasi lemak dan laktosa susu, solid non-fat dan total solid susu, namun memberikan dampak terhadap produksi dan konsentrasi protein susu pada sapi perah awal laktasi.

Kata kunci: Suplementasi, High Rumen Undegraded Protein, Produksi Susu, Kualitas Susu, Sapi Perah
\end{abstract}

\begin{abstract}
This research was aimed to determine the impact of balanced energy and protein supplementation with high rumen undegraded protein (HRUP) to milk production and quality in early lactating dairy cows. Twelve early lactating Friesian Holstein cows were divided into two groups (control and HRUP). Both control and HRUP group were fed on a basal diet (forage to concentrate ratio was 60:40; DM basis), with rumen undegraded protein (RUP) levels were $27.47 \%$ and $32.78 \%$ for control and HRUP, respectively. The experimental diets were given to animals twice daily, morning and afternoon. Water was given by ad libitum. The observed parameters were nutrient intake, quantity and quality of milk production . Data were examined using t-test. Results showed that feed intake, milk production and $4 \%$ FCM, milk fat and lactose concentrations, and milk solid non-fat and total solid concentrations were not differed significantly between control and HRUP groups. However, milk protein concentration and production were differed $(\mathrm{P}<0.05)$ between controls and HRUP groups. The balanced energy and protein supplementation with HRUP in early lactating dairy cows could impact on milk protein concentration
\end{abstract}


and production.

Key words: Supplementation, High Rumen Undegraded Protein, Milk Production and Quality, Dairy Cows

\section{INTRODUCTION}

The nutrient requirement of dairy cows increases with milk production, but high producing cows in early lactation are in capable to consume sufficient dry matter (DM) to support an optimal milk production. High production dairy cows requires high energy and protein diets during early lactation, because energy and protein are mobilized from body stores to support high milk production (NRC, 2001). The transition period for a dairy cow is from 3 to 2 week prepartum until 2 to 3 week postpartum. The term transition is to underscore the important physiological, metabolic, and nutritional changes occurring in this time frame. This constitutes a turning point in the productive cycle of the cow from one lactation to the next. The manner in which these changes occur and how they are managed are of great importance as they are closely linked to dry matter intake, lactation performance, clinical and subclinical postpartum diseases, and reproductive performance that can significantly affect profitability (Block, 2010).

The source of dietary crude protein $(\mathrm{CP})$ and energy fed to dairy cows influences the utilization of nitrogen and energy in the rumen and the flow of nutrients to the small intestine. Microbial synthesis in the rumen is incapable of providing sufficient protein to the high producing cows, and recommendation has been developed for undegraded intake protein or rumen undegraded protein (RUP) and high quality of essential amino acid profile of bypass protein (NRC, 2001). Because ruminal undegraded protein may increase the total amount of essential amino acid that is delivered to the small intestine and modify their profile (Calsamiglia et al., 1995; Calsamiglia et al., 2007; Ahari et al., 2011), adequate supply of protein to the small intestine of lactating dairy cows is essential for optimum milk production. Roseler et al. (1993) and Kohn (2007) reported that the ration lease excess degraded protein in the rumen will have high endogenous urea concentration in blood, milk and urine. This high concentration of urea will lead to fertility problem, decline of energy availability, environmental pollution and economic losses.

Milk protein production efficiency was influenced by the ratio of protein and energy availability for milk production (Santos et al., 1998; Mahr-un-Nisa, 2008). Besides, this was also influenced by the level of milk production and stage of lactation period. Flis and Wattiaux (2005) and Gulati et al. (2005) report that increased in the level of RUP in the ration had a positive effect on milk production and milk protein and fat concentrations (Chaturvedi and Walli, 2001) in lactating cows during early lactation. The purpose of this research was to examine the influence of balanced energy and protein supplementation with HRUP on milk production and quality in early lactating dairy cows.

\section{MATERIALS AND METHODS}

This research used 12 early lactating Friesian Holstein cows after parturition with an average live body weight of $\pm 445 \mathrm{~kg}$ and in the $2^{\text {nd }}$ or $3^{\text {rd }}$ lactating seasons. The animals were randomly divided into two equal and similar groups and fed on a basal diet (Table 1). The animals were housed in individually, permanent enclosure models stanchion barn with cement floors. Six cows were as a control group and other six cows were as HRUP group. King grass and concentrate were distributed two times a day at 09:00 am and $02.00 \mathrm{pm}$ with the proportion of 60:40 (DM basis). King grass was chopped size 15 to $20 \mathrm{~cm}$ and given 3 hours after concentrate distribution. The concentrate ingredients formulation and nutrient compositions of experimental diets for each groups were described in Table 1. Drink water were given by ad libitum.

The research was conducted for 3 months or 100 day, i.e. 10 day of adaptation period and 90 day of collection period. Milking was done twice a day, at 05:00 am and 01:00 pm. The milk production was recorded daily, and samples of milk were taken $5 \%$ of total production both in the morning and afternoon every two once weeks. Each sample of milk was composed of each cow, and was subjected to the determination of protein (Kjeldahl method), fat (Babcock method), lactose (Nelson method), solid non-fat, and total solid (AOAC, 2006) contents. At the beginning and end of the study, the cow was weighed before morning 
feeding. Analysis of samples was conducted in Laboratory of Dairy Science and Milk Industry, Faculty of Animal Science Gadjah Mada University.

The data of nutrient intake, milk production and milk quality (fat, protein, lactose, solid nonfat, and total solid) were examined using t-test analysis at $\mathrm{P}<0.05$. All the statistical analysis was performed using Statistical Program for Social Science or SPSS version 16.0.

\section{RESULTS AND DISCUSSION}

\section{Feed and Nutrient Intake}

Chemical composition of feed ingredients concentrates consist of: G-Pro, soy bean mealHCHO, kapok seed meal, copra meal, corn gluten feed, wheat pollard, palm kernel meal, coffee husk, corn tumpi, cassava waste, molasses, and mineral mix; and forages is was King grass. Content ingredients and nutrient compositions of experimental diet are shown in Table 1.

The feed and nutrient intakes of both groups did not affected by the treatment (Table 2). This result was similar to the study of Widyobroto et al. (2010), the increase of RUP in the ration did not influenced the intake of DM. The intake of organic matter $(\mathrm{OM})$ was improved as decreasing RUP amount in the current study. These observations were in accordance with those of Kiran and Mutsvangwa (2007), the increasing dietary rumen degraded protein (RDP) from $60 \%$ to $70 \%$ of $\mathrm{CP}$ increases the $\mathrm{OM}$ intake (ranging from 1.2 to $1.4 \mathrm{~kg} / \mathrm{d}$ ) in growing lambs. The dietary RDP may promote intake by enhancing gastrointestinal motility (Egan and Moir, 1965). Parakkasi (1995) stated, most factor that may affects the feed consumption is feed quality. The Consumption of OM is positively correlated with dry matter intake (DMI).

There are many information on the effects of forages : concentrates $(\mathrm{F}: \mathrm{C})$ ratio on DMI, growth performance and production in housing-feeding cows. In this study, the ratio of F:C were 60:40, with RUP value of $27.47 \%$ and $32.78 \%$ for control and HRUP groups, respectively. Both diets showed a normal cow performance. Cantalapiedra-Hijar et al. (2009) reported that DMI is not affected by the increasing ratio of concentrate in the diet from $30 \%$ to $70 \%$ in goats. Aguerre et al. (2011) found that increasing F:C ratios $(47: 53,54: 46,61: 39$, and 68:32) in the diet had no effect on DMI of Holstein cows. A similar result was observed by Agle et al. (2010), no change in DMI of lactating dairy cows fed diets contained $52 \%$ and $72 \%$ concentrate feeds. In contrast, Desnoyers et al. (2008) reported that DMI of dairy goats was increased (2.69 to 2.88 $\mathrm{kg} / \mathrm{d})$ with increasing the percentage of concentrate in the diet from $30 \%$ to $60 \%$. Murphy et al. (2000) noted that cows fed 30:70 diets of F:C ratio had a significantly higher DMI than cows fed 50:50 diets.

Dietary fibre content (CF) had no influence on OM intake in this trial. Commonly, an increase in dietary CF can be achieved by increasing the level of concentrates. Therefore, the results of the current study were comparable with those obtained by Cantalapiedra-Hijar et al. (2009) and Ramos et al. (2009), who found no effect of dietary concentrate : forage ratios (30:70 and 70:30) on OM intake in both goats and sheep fed above maintenance. The differences in $\mathrm{CF}$ of the diets were mainly due to the variance in $\mathrm{CF}$ concentrations. However, Allen (2000) noted that no effect of CF ranging from $25 \%$ to $40 \%$ was found on DM intake in dairy cows, although feed intake generally decreases with increasing $\mathrm{CF}$. $\mathrm{CF}$ in concentrate was high (coffee husks and corn tumpi), hence the need/requirement of fiber still can be fulfilled. This means that the intake of forages was low, the negative effect in the digestive process was not happened since the concentrates given still have high structural carbohydrates. This condition could be used as a reference by farmers, especially in the dry season where the forages were difficult to get and relatively expensive. Miller (1979) reported that the energy could affect the efficiency of the ration used, excess energy in ration, and also caused decrease ration efficiency used and tended to be accumulated in the body fat. One of the disadvantage was the excess of the amino acids is increased further and these need to be deamination and excreted, with consequent reduction in the energy value of the diet and increased pollution. The high protein intake was caused by concentrate level in ration with high protein content. However, the ratio of energy : protein in the diet should create a better protein efficiency. Thus, a better protein efficieny may protect feed protein from the ruminal degradation. In this study, the balanced intake of energy and protein of both diets were more than enough to fulfill the need of maintenance and production.

\section{Milk Production and Quality}

The result of production and milk quality is 
Table 1. Concentrate Ingredients Formulation and Nutrient Compositions of Experimental Diet

\begin{tabular}{|c|c|c|}
\hline \multirow{2}{*}{ Concentrates Formulation } & \multicolumn{2}{|c|}{ Group } \\
\hline & Control & HRUP \\
\hline & ----------. & - \\
\hline \multicolumn{3}{|l|}{ Ingredients } \\
\hline G-Pro & 8.0 & 3.0 \\
\hline Soy bean meal-HCHO & - & 9.0 \\
\hline Kapok seed meal & 6.0 & 6.0 \\
\hline Copra meal & 14.0 & 12.0 \\
\hline Corn gluten feed & 10.7 & 10.0 \\
\hline Wheat pollard & 16.7 & 14.0 \\
\hline Palm kernel meal & 13.4 & 13.0 \\
\hline Coffee husk & 14.3 & 11.0 \\
\hline Corn tumpi & 3.3 & 7.0 \\
\hline Cassava waste & - & 4.0 \\
\hline Molasses & 8.3 & 6.0 \\
\hline Mineral mix & 5.3 & 5.0 \\
\hline Total & 100 & 100 \\
\hline \multicolumn{3}{|l|}{ Analyzed compositions } \\
\hline $\mathrm{DM}$ & 88.24 & 89.06 \\
\hline $\mathrm{OM}$ & 87.93 & 88.37 \\
\hline $\mathrm{CP}$ & 18.55 & 18.83 \\
\hline $\mathrm{CF}$ & 16.81 & 16.06 \\
\hline $\mathrm{EE}$ & 5.10 & 4.70 \\
\hline $\mathrm{RUP}^{\mathrm{a}}$ & 27.47 & 32.78 \\
\hline $\mathrm{RDP}^{\mathrm{a}}$ & 63.55 & 60.84 \\
\hline $\mathrm{TDN}^{\mathrm{b}}$ & 56.94 & 58.91 \\
\hline
\end{tabular}

$\mathrm{DM}=$ Dry matter; $\mathrm{OM}=$ Organic matter $; \mathrm{CP}=$ Crude protein $; \mathrm{CF}=$ Crude fibre; $\mathrm{EE}=$ Ether extract; $\mathrm{RUP}=$ Rumen undegraded protein; RDP $=$ Rumen degraded protein; TDN $=$ Total digestible nutrient.

$\mathrm{a}=$ The results of the analysis in sacco degradation and formula of Widyobroto et al. (1997)

$\mathrm{b}=$ The results of the formula of Hartadi et al. (2005).

presented the Table 3. The result showed that milk production and 4\% FCM (fat corrected milk), milk fat concentration and production, milk lactose concentration and production, SNF and TS concentrations were similar between control group and HRUP groups. However, milk protein concentration and production were differed $(\mathrm{P}<0.05)$ between control group and HRUP groups. Production and composition of milk varies with the uptake of nutrients by the mammary gland, and this is influenced by mammary blood flow and utilization of nutrients by mammary gland (Kume and Tanabe, 1993). Most research suggested that increasing energy intake increases both concentration and production of protein in milk, and milk production is improved by increasing CP intake (DePeters and Cant, 1992). 
Table 2. Nutrient Intake of Dairy Cows Receiving Control and HRUP Supplementation

\begin{tabular}{lcc}
\hline \multirow{2}{*}{ Nutrient $(\mathrm{kg}$} & \multicolumn{2}{c}{ Ration } \\
\cline { 2 - 3 } DM/head/d) & Control & HRUP \\
\hline Forages & & \\
DM & 7.15 & 7.09 \\
OM & 6.21 & 6.16 \\
CP & 0.67 & 0.66 \\
CF & 2.35 & 2.34 \\
TDN & 4.09 & 4.05 \\
Concentrate & & \\
DM & 4.49 & 4.45 \\
OM & 3.95 & 3.93 \\
CP & 0.83 & 0.84 \\
CF & 0.75 & 0.71 \\
TDN & 2.53 & 2.62 \\
Total intake & & \\
DM & 11.64 & 11.54 \\
OM & 10.15 & 10.10 \\
CP & 1.50 & 1.50 \\
CF & 3.10 & 3.05 \\
TDN & 6.63 & 6.67 \\
\hline
\end{tabular}

$\mathrm{DM}=$ Dry matter; $\mathrm{OM}=$ Organic matter; $\mathrm{CP}=$ Crude protein; $\mathrm{CF}=$ Crude fiber; $\mathrm{TDN}=$ Total digestible nutrient.

The balanced intake of energy and protein with rumen undegraded protein supplementation may increase the amount of protein in the small intestine. The increased protein supply to the intestine was expected to meet the protein needs for milk production, thus increasing milk production in this study. This was similar to the work of Petit and Tremblay (1995), the strategy to increase the amount of proteins which can reach in the small intestine is to increase microbial protein synthesis or RUP supplementation. In this study, the supplementation of RUP in diet was intended to increase the amount of protein reaching in the small intestine. The increasing of RUP intake will increase the total amount of protein in the small intestine (Widyobroto, 1992).

The increase of in milk production in this research was in line with the tendency of the decline of fat milk. The decrease of fat milk was due to the low fiber in the ration with supplementation of RUP, hence decreased of resulting in low $\mathrm{pH}$ and ammonia production. This was similar to the results of Hristov et al. (2004a, 2004b), the energy source of feed material easily fermented in the rumen can decrease rumen ammonia concentration by reducing the production of ammonia, or by increasing ammonia uptake for microbial protein synthesis. The energy easily fermented in the rumen will lower the ammonia production continously but as a whole efficiency of ammonia used for milk protein synthesis, this will only increase with by increasing ammonia uptake by rumen microbes.

The average milk production was higher in cow with HRUP supplementation resulting in the low variation of daily production. Figure 1 showed that daily milk production in cows with HRUP supplementation was increased consistently compared to the control group. This phenomenon is quite interesting to further scrutiny during the period of lactation, so that the persistence of milk production during lactation period can be evaluated.

Although the response of cow with balanced energy and protein supplementation on milk production and milk constituent was quite good compared with control, but the production level was still under optimum level compared with results in developed countries $( \pm 9.0 \mathrm{~L} / \mathrm{head} /$ day $)$. Santos et al. (1998) reported that the low production of dairy cows (4500 kg/lactation) is able to meet protein needs for microbial protein synthesis. In contrast, the high production of dairy cows (9000 to $14000 \mathrm{~kg}$ /lactation) requires a sufficient source of undegraded protein to be used directly in the intestine. The results of this research was similar to Hristov et al. (2004a, 2004b), dry matter intake, milk production, fat and milk protein are not statistically different between rations containing high rumen degraded protein (HRDP) and those with sufficient RDP. Furthermore, Dunlap et al. (2000) stated that there is tendency of higher nitrogen $(\mathrm{N})$ excretion in urine, blood plasma and milk urea nitrogen concentrations resulted from HRDP ration than that of RDP ration. The value of efficiency $\mathrm{N}$ in milk is decreased in the HRDP rations. The RDP ration for lactating cow was not efficiently used for microbial protein synthesis and most excreted with the secretion of $\mathrm{N}$ urine. The increase of $\mathrm{CP}$ or RDP concentration in the ration would decrease 
Table 3. Average Milk Production, 4\% FCM and Milk Quality Dairy Cows Receiving Control and HRUP Supplementation

\begin{tabular}{|c|c|c|c|}
\hline \multirow{2}{*}{ Parameters } & \multicolumn{2}{|c|}{ Group } & \multirow{2}{*}{ Statistic } \\
\hline & Control & HRUP & \\
\hline Milk production (L/head/day) & $10.71 \pm 1.64$ & $12.39 \pm 2.88$ & ns \\
\hline Production 4\% FCM (kg/head/day) & $9.29 \pm 1.17$ & $10.49 \pm 2.45$ & ns \\
\hline Milk fat (\%) & $3.05 \pm 0.19$ & $2.88 \pm 0.17$ & ns \\
\hline Milk fat production (kg/head/day) & $0.14 \pm 0.01$ & $0.15 \pm 0.03$ & ns \\
\hline Milk protein $(\%)$ & $2.57 \pm 0.15$ & $3.02 \pm 0.12$ & $*$ \\
\hline Milk protein production $(\mathrm{kg} /$ head/day) & $0.12 \pm 0.02$ & $0.16 \pm 0.04$ & $*$ \\
\hline Milk lactose (\%) & $5.90 \pm 0.33$ & $5.62 \pm 0.48$ & ns \\
\hline Milk lactose production (kg/head/day) & $0.28 \pm 0.05$ & $0.29 \pm 0.02$ & ns \\
\hline Solid non fat $(\%)$ & $8.47 \pm 0.26$ & $8.63 \pm 0.42$ & $\mathrm{~ns}$ \\
\hline Total solid $(\%)$ & $11.53 \pm 0.37$ & $11.52 \pm 0.42$ & ns \\
\hline
\end{tabular}

$*=$ Significant $(\mathrm{P}<0.05) ; \mathrm{ns}=$ Non significant $(\mathrm{P}>0.05)$.

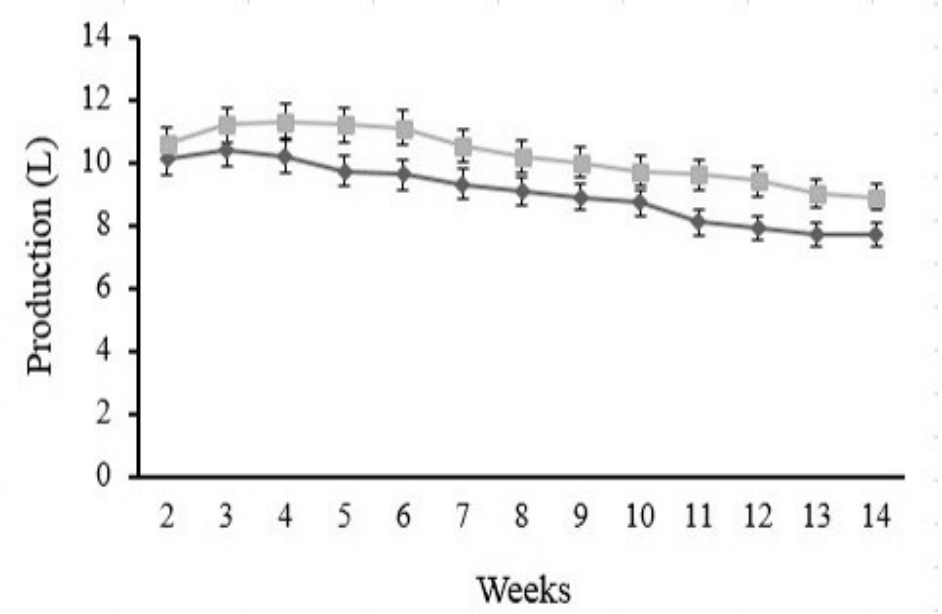

Figure 1. Average Milk Production of Dairy Cows Receiving Control and HRUP Supplementation (14 Weeks of Collection Period). $\longrightarrow$ Control, $\longrightarrow$ HRUP

efficiency of $\mathrm{N}$ conversion from the ration to milk protein and less efficient used of rumen ammonia $\mathrm{N}$ for milk protein synthesis.

\section{CONCLUSION}

The conclusion is balanced energy and protein supplementation with HRUP to milk production and quality in early lactating dairy cows would not impact on milk production and
4\% FCM, milk fat and lactose concentration and production, milk solid non-fat and total solid concentration. However, this would be impact on milk protein concentration and production in early lactating dairy cows.

\section{ACKNOWLEDGEMENTS}

This research was funded by Faculty of Animal Science Gadjah Mada University through 
"Hibah Penelitian Pascasarjana Fakultas Peternakan UGM", No. 555/701.1.1.25/PPs/16 Juli 2013 and supported facilities by Department of Agriculture Daerah Istimewa Yogyakarta, Indonesia.

\section{REFERENCES}

Agle, M., A.N. Hristov, S. Zaman, C. Schneider, P.M. Ndegwa, and V.K. Vaddella. 2010. Effect of dietary concentrate on rumen fermentation, digestibility, and nitrogen losses in dairy cows. J. Dairy Sci. 93: 42114222.

Aguerre, M.J., M.A. Wattiaux, J.M. Powell, G.A. Broderick, and C. Arndt. 2011. Effect of forage-to-concentrate ratio in dairy cow diets on emission of methane, carbon dioxide, and ammonia, lactation performance, and manure excretion. J. Dairy Sci. 94: 3081-3093.

Ahari, K.M., R. Salamatdoustnobar, N. MaheriSis, A. Gorbani, A.H. Shabestari, A. Noshadi, H. Samadi, and J.S. Nezhad. 2011. Effects of the thyme extract on the ruminal methane production. Pak. J. Nutr. 10:11461148.

Allen, M.S. 2000. Effects of diet on short-term regulation of feed intake by lactating dairy cattle. J. Dairy Sci. 83: 1598-1624.

AOAC. 2006. Methods of Analyses. Association of Official Analytical Chemists. 16Ed. Publ, AOAC.

Block, E. 2010. Transition cow research - what makes sense today? Proceedings of The High Plains Dairy Conference does not support one product over another and any mention herein is meant as an example, not an endorsement. Amarillo-Texas, pp. 75-98.

Calsamiglia, S., G. Caja, M.D. Stern, and B.A. Crooker. 1995. Effects of ruminal vesus duodenal dosing of fish meal on ruminal fermentation and milk composition. J. Dairy Sci. 78:1999-2007.

Calsamiglia, S., M. Busquet, P. W. Cardozo, L. Castillejos, and A. Ferret. 2007. Invited review: Essential oils as modifiers of rumen microbial fermentation. J. Dairy Sci. 90: 2580-2595.

Cantalapiedra-Hijar, G., D.R. Yáñez-Ruiz, A.I. Martín-García, and E. Molina-Alcaide. 2009. Effects of forage: Concentrate ratio and forage type on apparent digestibility, ruminal fermentation, and microbial growth in goats. J. Anim. Sci. 87:622-631.

Chaturvedi, O.H. and T.K. Walli. 2001. Effect of feeding graded levels of undegraded dietary protein on voluntary intake, milk production and economic return in early lactating crossbred cows. Asian-Aust. J. Anim. Sci. 14:1118-1124.

Chiou-Shyang-Peter, W., C. Kuen-Jaw, K. KwenSheng, H. Jenn-Chung, and B. Yu. 1995. Studies on the application of an undegradable system to high yielding dairy cattle in Taiwan. Anim. Feed Sci. Technol. 54:93-102.

DePeters, E.J. and J.P. Cant. 1992. Nutritional factors influencing the nitrogen composition of bovine milk: a review. J. Dairy Sci. 75: 2043-2070.

Desnoyers, M., C. Duvaux-Ponter, K. Rigalma, S. Roussel, O. Martin, and S. Giger-Reverdin. 2008. Effect of concentrate percentage on ruminal $\mathrm{pH}$ and time-budget in dairy goats. J. Anim. Sci. 2: 1802-1808.

Dunlap, T.F., R.A. Kohn, L.W. Douglass, and R.A. Erdman. 2000. Diets deficient in rumen undegraded protein did not depress milk production. J. Dairy Sci. 83:18061812.

Egan, A.R. and R.J. Moir. 1965. Nutritional status and intake regulation in sheep: I. Effects of duodenally infused single doses of casein, urea, and propionate upon voluntary intake of a low-protein roughage by sheep. Crop Pasture Sci. 16:437- 449.

Flis, S.A. and M.A. Wattiaux. 2005. Effects of parity and supply of rumen-degraded and undegraded protein on production and nitrogen balance in Holsteins. J. Dairy Sci. 88:2096-2106.

Gulati, S.K., M.R. Garg and T.W. Scott. 2005. Rumen protected protein and fat produced from oil seeds and meals by formaldehyde treatment; their role in ruminant production and product quality: A review. Aust. J. Exp. Agric. 45:1189-1203.

Hartadi, H., S. Reksohadiprodjo, dan A.D. Tillman. 2005. Tabel Komposisi Pakan Untuk Indonesia. Gadjah Mada University Press. Yogyakarta.

Hristov, A.N., R.P. Etter, J.K. Ropp, and K.L. Grandeen. 2004a. Effect of dietary crude protein level and degradability on ruminal fermentation and nitrogen utilization in lactating dairy cows. J. Anim. Sci. 82: 32193229 . 
Hristov, A.N., J.K. Ropp, K.L. Grandeen, S. Abedi, R.P. Etter, A. Melgar, and A.E. Foley. 2004b. Effect of carbohydrate source on ammonia utilization in lactating dairy cows. J. Anim. Sci. 83:408-421.

Kiran, D. and T. Mutsvangwa. 2007. Effects of barley grain processing and dietary ruminally degradable protein on urea nitrogen recycling and nitrogen metabolism in growing lambs. J. Anim. Sci. 85:33913399.

Kohn, R. 2007. Use of milk or blood urea nitrogen to identify feed management inefficiencies and estimate nitrogen excretion by dairy cattle and other animals. Proceedings of Florida Ruminant Nutrition Symposium, January 30-31, 2007, Gainesville-Florida, pp: 1-15.

Kume, S. and S. Tanabe. 1993. Effect of parity on colostral mineral concentrations of Holstein cows and value of colostrum as a mineral source for newbom calves. J. Dairy Sci. 76: 1654-1660.

Mahr-un-Nisa, A. Javaid, M. Aasif Shahzad and M. Sarwar. 2008. Influence of varying ruminally degradable to undegradable protein ratio on nutrient intake, milk yield, nitrogen balance, conception rate and days open in early lactating Nili-Ravi Buffaloes (Bubalus bubalis). Asian-Aust. J. Anim. Sci. 21:1303-1311.

Miller, W.J. 1979. Dairy Cattle Feeding and Nutrition. Academic Press, New York, San Fransisco, London.

Murphy, M., M. Akerlind, and K. Holtenius. 2000. Rumen fermentation in lactating cows selected for milk fat content fed two forage to concentrate ratios with hay or silage. J. Dairy Sci. 83:756-764.

NRC. 2001. Nutrient Requirements of Dairy Cattle. $7^{\text {th }}$ Edition. National Academic Science. Washington, D.C.

Parakkasi, A. 1995. Ilmu Nutrisi dan Makanan Ternak Ruminan. Universitas Indonesia
Press. Jakarta.

Petit H.V. and G.F. Tremblay. 1995. Ruminal fermentation and digestion in lactating cows fed grass silage with protein energy supplements. J. Dairy Sci. 78:342-357.

Ramos, S., M.L. Tejido, M.E. Martínez, M.J. Ranilla, and M. D. Carro. 2009. Microbial protein synthesis, ruminal digestion, microbial populations, and nitrogen balance in sheep fed diets varying in forage-toconcentrate ratio and type of forage. J. Anim. Sci. 87:2924-2934.

Roseler, D.K., J.D. Ferguson, C.J. Sniffen, and J. Herrema. 1993. Dietary protein degradability effects on plasma and milk urea nitrogen and milk nonprotein nitrogen in Holstein cows. J. Dairy Sci. 76: 525-534.

Santos, F.A.P., J.E.P. Santos, C.B. Theurer, and J.T. Huber. 1998. Effect of rumen undegradable protein on dairy performance. A 12-year literatur review. J. Dairy Sci. 81: 3182-3213.

Widyobroto, B.P. 1992. Influence de la proportion et de la nature du concentre sur les sites et la dynamique de la digestion chez la vache haute productrice. These Docteur de l'Universite de Rennes I. France.

Widyobroto, B.P. 1997. Pengaruh perlakuan formaldehid pada bungkil kedelai terhadap degradasi protein dalam rumen dan kecernaan undegraded protein di intestinum [Effect of formaldehide treatment to soybean meal on protein degradation in the rumen and digestibility of undegraded protein in the intestine]. Proceedings of Seminar Nasional II Ilmu Nutrisi dan Makanan Ternak. Faculty of Animal Science Bogor Agriculture University, Bogor, Indonesia, July 15-16, 1997. P. 33-34.

Widyobroto, B.P., S.P.S. Budhi, and A. Agus. 2010. Effect of protein undegraded supplementation on production and composition of milk in dairy cows. J. Indonesian Trop. Anim. Agric. 35:27-33. 